\title{
The Using of Short Stories to Enhance Students' Reading Comprehension
}

\section{Yustina Jeni}

Universitas Widya Gama Mahakam, Indonesia

Email Correspondence: yustinajeni17@gmail.com

\begin{abstract}
The study uses classroom action research. This study also to solve the problems in the class and it also has a cycle with four steps. The data were collected by observation, learning test results, and documentation. This study involved 35 students in eight grade of SMPN 5 Samarinda. This study was carried out in one cycle. It also showed that there is an enhancement in students' learning results. In addition, it can be said that the use of short stories during the teaching and learning process is very effective to enhance students' reading comprehension. This is due to the enthusiasm of students to join the process and short stories that are exciting to read. Hence, the students' mean score indicated that there is an enhancement during the teaching and learning process using short stories. Using short stories as teaching material and strategy in teaching is a very good way, especially to enhance their reading comprehension. This is because short stories provide motivation through moral lessons and get students involved in learning activities. Short stories also give students time to interact with the text by reading the whole story from various short stories. Besides, short stories are also exciting because short stories are very diverse and it enriches students' vocabulary. Finally, short stories also make students think critically through what is conveyed by the stories.
\end{abstract}

Keywords: Strategy; Short Stories; Reading Comprehension

\begin{tabular}{|c|c|c|}
\hline DOI & $:$ & https://doi.org/10.24903/bej.v2i2.632 \\
\hline Received & : & February 2020 \\
\hline Accepted & : & June 2020 \\
\hline Published & : & August 2020 \\
\hline $\begin{array}{l}\text { Copyright and } \\
\text { License }\end{array}$ & : & $\begin{array}{l}\text { Authors retain copyright and grant the journal right of first publication with the } \\
\text { work simultaneously licensed under a Creative Commons Attribution } \mathbf{4 . 0} \\
\text { International License that allows others to share the work with an acknowledgement of } \\
\text { the work's authorship and initial publication in this journal. } \\
\text { CC }\end{array}$ \\
\hline
\end{tabular}




\section{INTRODUCTION}

This Reading as a process of learning, and it also a part of students' daily activities. Students can get benefits through reading and understand the written text. According to [1] reading is a process of developing meaning from the text. They also mention that it is a process in which students actively search in making meaning in what they read, and it also referred to making meaning from the text and process that students can use to get information or understand about the reading comprehension text.

The reading comprehension needs a process, students with teacher supervision correct and sees the development of students in reading comprehension, especially when they are looking for meaning from the words. Meanwhile, [2] argues that reading is an excellent source of comprehensible input that enhances second language acquisition. Besides, reading short stories can develop students' reading comprehension because it is suitable for them. Reading comprehension, reading habits, and reading interest have a positive correlation. That is why the teacher should help students to develop their reading comprehension through the strategy.

In the learning process, the students have to catch the meaning and understand the written text, but most of the Indonesian students; their reading level is low because they are difficult to understand the text in reading comprehension. Regarding the results of the interview with the teacher, the researcher concludes that short stories are a suitable way to enhance students' reading comprehension. The difficulties that they experienced, they do not know some words of the reading passage, it is problematic for them to get the words but it makes them have to face reality if reading is complicated, so that is why they do not know the word from the passage. Also, [3] stated that difficulties because of boring teaching and learning material. Therefore, short stories are effective in developing their reading comprehension.

Moreover, [4] stated the challenges from the textbook seem more delicate and tricky. On the other hand, it uses complex vocabulary, and the way the teacher teaches it is also not fascinating, the teacher needs to encourage student interest in reading. The researcher can conclude that reading is the process that must be achieved. Therefore, an exciting strategy to enhance students' reading comprehension and catch the meaning of reading is short stories. The use of short stories in English teaching needs to apply what is needed to be learned to encourage the students. However, the teacher plays a proper role, and the teacher should select an acceptable text to use for the student and may facilitate their students to perceive the story with varied activities. 
According to [5] story choice is so one of the foremost vital roles of the teacher. Since the lengths of short stories quite vary, select a story short enough to handle inside course hours. Using short stories with simple language can make students comfortable to understand. It is also useful and suitable for the student to enhance their reading comprehension because it provides an exciting and useful story to read, also it has various interesting topics, and it has a picture that can make the student interested to read. According to [6] short stories should interest students, therefore they can enjoy while learning reading comprehension through short stories and it can lead them become a critical thinker; they will be entertained with short stories that are provided by the teacher. According to [7] The pleasant short stories will motivate them and propose a fictional and interesting world. The researcher use short stories as a strategy to help the student enhance their reading comprehension and the researcher hopes by this, students will not have problems in comprehend reading.

\section{METHODOLOGY}

This study uses classroom action research as the research design. Hence, it occurs in the classroom to increase students' understanding, and this study focuses on the teaching and learning activities in the class. This action was designed to enhance students' reading comprehension. The researcher found and the students having problems in reading comprehension, specifically the students having difficulties understanding reading material. Therefore, short stories are suitable to help the students understand reading material. In implementing the action, the researcher acted as teacher and the observer filled the observation sheets that includes students' activities and researcher's performances.

In implementing the study, the cycle includes four steps. If the actions of the cycle show a positive result and reach the criteria of success, then the action would stop. But if the cycle did not reach the criteria of success, the action will be implemented. The study was conducted at SMPN 5 Samarinda which is located in Jl. Juanda No.18, Air Putih, Samarinda. It involved 35 students. The researcher implemented the material by using short stories. To collect the data, the researcher uses observation, learning test results, and documentation. The instrument was observation sheets and the test. The score obtained from the test given by the researcher. Hence, the mean score used in this study to describe the enhancement in students' learning outcomes by using the mean scores in each meeting. This quantitative data is obtained by calculating students' mean score of the results, and also to find the mean score, it uses the formula.

$$
\underline{x}=\frac{\sum x}{n}
$$

Description: 


$$
\begin{array}{ll}
\underline{x} & : \text { The mean score } \\
\sum x & : \text { The sum of students' score } \\
\mathrm{N} & : \text { Total number of the students }
\end{array}
$$

\section{FINDINGS}

The process of teaching and learning by using short stories has been done in four steps that consist of these cycle. The researcher focuses on how short stories can enhance students' reading comprehension. Therefore, the researcher repeated and asked the student to answer and read seriously.

\subsection{Pre-Activity}

The activity in this stage is greeting the students. After that, the researcher checked the students' attendance list. To ensure that all students were present, the researcher called them one by one. Besides, to induce students' attention, the researcher asked some questions related to the topic on that day. The class was noisy; therefore, the researcher told them the topic on that day was about. In this stage, a question and answer session was conducted.

\subsection{Whilst-Activity}

First of all, the researcher distributed the test. After that, discusses the material and asks them what's the difficulties in comprehending reading after they read the story, the researcher also asked based on the story such as "what kind of the story? "What can be obtained from the story?" "How many antagonist roles in the story?" Then whether short story makes it easy for them to understand reading.

\subsection{Post-Activity}

In the last activity, the researcher collected students' work, gave evaluation and closed the meeting.

\section{DISCUSSION}

This study aims to describe how short stories can enhance students' reading comprehension. Research Question: How can short stories enhance students' reading comprehension?

After conducted the study and from the result of the study, the researcher found that teaching reading in eight grade students of SMPN 5 Samarinda by short stories can enhance students' comprehension. Moreover, teaching students by using short stories is also effective and can help students comprehend especially in reading. This is similar to a study conducted by [8]. She found that the results showed enhancement in students. In this study, the researcher also found the same finding. 
In the first meeting until the last meeting, there are several activities, namely preactivity, whilst-activity and post-activity. In pre-activity, the researcher opened the class and carried out plans prepared. In whilst activity, researcher conducted some steps by asking the students. First, researcher inquired the students to read and tried to understand the story given. Second, the students read the whole text and the researcher conducted the discussion. Third, after conducted the discussion, the researcher asked the students to answer the questions and the researcher provided motivation and comments in order to make the students know whether their answer was correct or not. Through the following activities, the researcher can see students' interactions and how short stories could assist students comprehend reading material.

Regarding the result of the following activities, the researcher found that students mean score in action one was 70.28. It increased in action two become 85.71, and the mean score from the last action was 87.71. Students learning results in all actions can be said successful because it reached the criteria of success. The results showed that there was an enhancement when using short stories because short stories are not complicated for students. This finding also confirmed by [9] he found that short stories are a good strategy because it is suitable, motivating students, fun, and it can help students to enhance their understanding.

From the findings of the study, the problem of the study answered that using short stories as a strategy in learning English can enhance students' reading comprehension in eight grade students of SMPN 5 Samarinda. This is because short stories are practical, it helps students to gain knowledge from what they have read, grow their critical thinking because of their interaction with the text.

\section{CONCLUSION}

Based on the findings and discussion of the study about the use of short stories to enhance students' reading comprehension in eighth grade, it can be concluded that this study answered the research question. The using of short stories can enhance students' reading comprehension. It can be seen from the mean score of student's results at all meetings and it reached the criteria of success.

In the first meeting of action one, the students' mean score was 70.28 and in action two, it was enhanced to 85.71. Then in the last meeting of action three, the students' mean score was enhanced to 87.71 . This change proves that using short stories as a strategy can help enhance students' reading comprehension. 
Using short stories as teaching material and strategy in teaching is a very good way, especially to enhance their reading comprehension. This is because short stories provide motivation through moral lessons and get students involved in learning activities.

Short stories also give students time to interact with the text by reading the whole story from various short stories. Besides that, short stories are also interesting because the stories are very diverse and it enriches students' vocabulary. Finally, short stories also make students think critically through what is conveyed by the stories.

\section{REFERENCES}

[1] F. Cline, C. Johnstone, and T. King, Focus Group Reactions to Three Definitions of Reading (As Originally Developed in Support of NARAP Goal 1). 2006.

[2] S. Krashen, "Stephen Krashen: Pleasure Reading," Young Learn. Sig, pp. 2-4, 2006.

[3] R. Boudaoud, “Arab World English Journal," Arab World English J., vol. 4, no. 2, pp. 160-172, 2013.

[4] W. Grabe and F. L. Stoller, Teaching and Researching Reading, 2nd ed. 2013.

[5] N. O. Ceylan, "Using Short Stories in Reading Skills Class," Procedia - Soc. Behav. Sci., vol. 232, pp. 311-315, 2016.

[6] P. Pardede, "Using Short Stories to Teach Language Skills," J. English Teach., vol. 1, no. 1, pp. 17-27, 2011.

[7] H. Vural, "Use of Literature to Enhance Motivation in ELT Classes," Mevlana Int. J. Educ., vol. 3, no. 4, pp. 15-23, 2013.

[8] M. P. Handayani, "Using Children Short Stories to Enhance Students' Reading Comprehension,” J. English Educ., vol. 1, no. 1972, pp. 196-205, 2013.

[9] Y. Kirkgöz, "Incorporating Short Stories in English Language Classes," NovitasROYAL, vol. 6, no. 2, pp. 110-125, 2012. 